Reprinted from

THE JOURNAL SOUTHEAST ASIAN HISTORY

(Vol. 5, No. 1) March 1964 (pp. 62-100)

\title{
The Chinese Mestizo in Philippine History
}

\author{
By \\ E. Wickberg
}

East Asian Series, Reprint No. 10

INTERNATIONAL STUDIES

CENTER FOR EAST ASIAN STUDIES

THE UNIVERSITY OF KANSAS

Lawrence, Kansas 


\section{CENTER FOR EAST ASIAN STUDIES}

1. The Patrimonial Thesis and Pre-Modern Japanese Herrschaft, by Norman Jacobs.

2. The Phantom Slasher of Taipei: Mass Hysteria in a Non-Western Society, by Norman Jacobs.

3. Early Chinese Economic Influences in the Philippines, by Edgar Wickberg.

4. Some Aspects of Korean Acculturation and Value Orientation Since 1950, by Felix Moos.

5. The Philippine Political Party System, by Carl H. Lande.

6. Religion and Politics in Japan: The Case of the Soka Gakkai, by Felix Moos.

7. Some Aspects of Park Chang No Kyo-A Korean Revitalization Movement, by Felix Moos.

8. The Philippines, by Carl H. Lande.

9. General Artemio Ricarte \& Japan, by Grant K. Goodman.

10. The Chinese Mestizo in Philippine History, by E. Wickberg. 
THE CHINESE MESTIZO IN PHILIPPINE HISTORY

E. WiCKBERG. 


\section{THE CHINESE MESTIZO IN PHILIPPINE HISTORY*}

\section{E. WickBerg.}

Students of Southeast Asian history have had little to say about the historical role played by the Chinese mestizo in that region. Although studies of the Chinese in Southeast Asia have devoted some attention to the position of native-born Chinese as opposed to immigrant Chinese, the native-born Chinese of mixed Chinesenative ancestry is rarely singled out for specific treatment. Perhaps this is because in most parts of Southeast Asia the Chinese mestizos (to use the Philippine term for persons of mixed Chinese-native ancestry) have not been formally and legally recognized as a separate group - one whose membership is strictly defined by genealogical considerations rather then by place of birth, and one which, by its possession of a unique combination of cultural characteristics, could be easily distinguished from both the Chinese and the native communities.

Such distinctiveness was, however, characteristic of the Chinese mestizo in the Philippines during the eighteenth and nineteenth centuries. Both the Spanish colonial government and the mestizos themselves concurred in this exact identification as neither Chinese nor native, but specifically Chinese mestizo. It is precisely because they formed a separate group, legally defined as such by the Spanish government, that we are able to determine with considerable clarity the nature of the mestizos' activities - and hence, the nature of their role in that period of Philippine history. That role was as I will attempt to demonstrate below, of great significance to Philippine historical development. Indeed, although close comparison is difficult, it is likely that no other group of mestizos - that is, not simply locally-born Chinese, but specifically mestizo Chinese-played a similar role in the development of a Southeast Asian country.

The present paper is a kind of preliminary research report. In it I will present my findings to date as well as some rather new interpretations of Philippine history that I have come to as a result of the work done thus far. I hope these interpretative comments

* The material in this article is partially derived from my forthcoming book, The Chinese in Philippine Economy and Society, 1850-1898 which is to be published by the Yale University Press. 


\section{THE CHINESE MESTIZO IN PHILIPPINES}

may stimulate discussion on both the mestizo and on broader problems in Philippine historiography.

\section{Background Discussion}

If the Chinese mestizo was important in the eighteenth and nineteenth centuries, and if Spanish legal distinctions make it easy for us to follow his activities during that period, why, then, is so little said about him in modern writings about Philippine history? Why has there been almost no research on this topic?

One of the answers seems to be that there is confusion about the term mestizo - a confusion compounded by the fact that since 1898 there has been no legally-defined mestizo class which we may use as a basis for understanding the Spanish usage of the term. It is sometimes claimed that Spanish mestizos were of great importance in Philippine history when, indeed, the activities described as support for this statement were those of Chinese mestizos. One recent. study, the Human Relations Area Files monograph on the Philippines, goes so far as to say that although they were of some importance during the first decades of the Spanish period, the Chinese mestizos faded into obscurity thereafter. ${ }^{1}$ Statements of this kind seem to be based upon the assumption that the term mestizo, when encountered in its unmodified form in materials of the Spanish period, refers to Spanish mestizos - that is, persons of mixed Spanish-native ancestry - rather than to Chinese mestizos. Because of this apparent confusion over the term mestizo, it is best to begin with a discussion of the distinctions that were made during the Spanish period - both by the Spanish government and by popular usage.

From the time that Chinese mestizos became numerous enough to be classified separately, the population of those parts of the Philippines that were controlled by Spain was formally divided into four categories: those who did not pay the tribute (which included Spaniards and Spanish mestizos), indios (Malayan inhabitants of the archipelago, who are now called Filipinos ${ }^{2}$ ), Chinese, and Chinese mestizos. The last three of these groups were considered tribute-paying classes, but the amount of their tribute payments and the services demanded of them varied. Normally, the indio paid the lowest tribute. The Chinese mestizo paid double the tribute paid by the indio, the stated reason being that he was

1. Human Relations Area Files, Area Handbook on the Philippines, ed. Fred Eggan (4 vols; Chicago, 1956), I, p. 440.

2. As indicated below, the term "Filipino", during most of the Spanish period, was used to indicate a Spaniard born in the Philippines. Because this article deals with social organization during Spanish times, the terms as used then are employed here for clarity's sack. Thus, the term "indio", as used here. is a neutral one, and is intended to reflect no discredit upon the Filipino. 


\section{THE CHINESE MESTIZO IN PHILIPPINES}

assumed to have approximately double the earning capacity of the indio. The Chinese, in turn, paid a much larger tribute than that paid by the Chinese mestizo, again, on the grounds that his earning capacity was larger than that of the mestizo. ${ }^{3}$ It would seem, therefore, that in Spanish thinking, biology and economics had a certain correlation.

On the other hand, Spanish policy may have been grounded more in economic and social reality than in bio-economic theory. Throughout most of the Spanish period the indio and mestizo also had to supply a fixed amount of forced labor every year, an obligation that did not fall upon the Chinese. It is possible that this requirement, taken together with other taxes, represented simply a recognition of the occupational facts of Philippine social life. The Chinese was, first and last, a commercially-oriented moneymaker. What he could best supply was money. At the other extreme was the indio, whose concerns were chiefly agricultural; what he could best supply, other than tribute grain, was labor. The Chinese mestizo was somewhere between - possibly engaged in agriculture, possibly in commerce, possibly in both.

In any event, the tribute-paying classes remained, until late in the nineteenth century, divided as indicated above. Why so? Aside from matters of theory and convenience in taxation as discussed above, one may cite the familiar political reason: divide and conquer. This is a simple, comfortable, and hence tempting answer. It is also not without validity for the middle and late nineteenth century Philippines. But we ought not to assume automatically that it was the basic reason why the Spanish, mid-way through the colonial period, established a policy of social compartmentalization. Indeed, there is some evidence that the separation of groups in this fashion was originally based upon no more than a Spanish belief that the healthy society was one in which peoples of different cultural backgrounds were kept apart and not allowed to live together in helter-skelter fashion. ${ }^{4}$

For whatever reason, indios, Chinese mestizos, and Chinese remained as three separate groups, especially in terms of tax obli-

3. John Phelan, The Hispanization of the Philippines (Madison, 1959), pp. 95, 97; Tomás de Comyn, "Estado de las Islas Filipinas en 1810," Las Islas Filipinas. Progresos en 70 años, ed. J. F. del Pan (Manila, 1877), p. 114; Victor Purcell, The Chinese in Southeast Asia (London, 1951), pp. 598-99; PNA (Philippine National Archives), Gremios de naturales, mestizos, y chinos, 16-5-5. Note that key numbers in references to PNA materials are based upon my own system, there being no comprehensive finding system for that archives.

4. See, for instance, an anti-gambling proclamation of 1800 in Miguel Rodríguez Berriz, Diccionorio de la administración de Filipinas... Anuario 1888 (2 vols; Manila, 1888), II p. 346. 


\section{THE CHINESE MESTIZO IN PHILIPPINES}

gations. But insofar as rights were concerned - such as rights to move about the islands, own property, or participate in town government - the division tended to be two-fold, rather than threefold. That is, in general, the mestizos had most of the same rights as the indios, while the Chinese usually did not. The case of property ownership is not clear. But in matters of geographic mobility, the Chinese were usually restricted (with varying degrees of success) while the mestizos, like the indios, were relatively free to change residence. ${ }^{5}$ Likewise, in local government, the Chinese could never participate, but Chinese mestizos, individually and corporately, could and did participate with the indios. ${ }^{6}$

The maintenance of three categories in orderly fashion was provided for by Spanish legislation. Legal status-as Chinese, mestizo, or Indio - by the terms of this legislation - was not ordinarily a matter of personal orientation or choice. Rather, it was the status of the parents - particularly the father - that was most important. Thus, the son of a Chinese father and an india or mestiza mother was classed as a Chinese mestizo. Subsequent male descendants were inalterably Chinese mestizos. The status of female descendants was determined by their marriages. A mestiza marrying a Chinese or mestizo remained in the mestizo classification, as did her children. But by marrying an indio she and her children became of that classification. ${ }^{7}$ Thus, females of the mestizo group could change status but males could not. The implications of this system was that so long as legislation remained constant there would always be a sizeable group of people legally classified as mestizos, whatever their cultural orientation might be. ${ }^{8}$

This posed a problem for mestizos who wished to be considered indios or Chinese, or for indios of mestizo heritage on their mother's side who might wish to be considered mestizo. But there is evidence that the system was not inflexible and that there were procedures by which one could change his status. The lineage history of José Rizal, as given by Austin Craig, is to the point here,

5. Recopilación de leyes de los reynos de las Indias (2nd ed; 4 vols; Madrid, 1756), libro 6, título 18, ley 3; Purcell, p. 598; BR (Emma H. Blair and James A. Robertson, ed., The Philippine Islands, 1493-1898 (55 vols; Cleveland, 1903-07), L, p. 200.

6. PNA, Gremios, 16-5-5; PNA, Provincial Documents, legajo 117, número 70. legajo 56, número 11.

7. Chinos. Sus reglamentos y sus contribuciones, comp. El Faro Administrativo (Manila 1893), pp i 13-14 PNA, Provincial Documents, legajo 56, número II.

8. The perpetuation of a mestizo group was also aided by the post 1800 marriage legislation, which tended to discourage mestizo-indio marriages. Joaquin Rodríguez San Pedro, Legislatión ultramarina (16 vols; Madrid, 1865-59), II, pp. 513-23; Rafacl Comenge, Cuestiones filipinas. l.a parte. Los chinos (Manila, 1894), p. 233. 


\section{THE CHINESE MESTIZOO IN PHILIPPINES}

Purely in terms of his ancestry, Rizal might be considered a fifthgeneration Chinese mestizo. His paternal ancestor, a Catholic Chinese named Domingo Lamco, married a Chinese mestiza. Their son and grandson both married Chinese mestizas. This grandson, having achieved wealth and status in his locality, was able to have his family transferred from the mestizo padron, or tax-census register, to that of the indios. Thus, Rizal's father, and Rizal himself, were considered indio.9

It would appear that individual dispensation was possible, given certain procedures. It is likely that the procedures in question were those widely used in Spanish colonial America in the late eighteenth century and called dispensa de ley, or gracias al sacar..$^{10}$ By these procedures, one paid a sum, a genealogy and other instruments of proof were prepared, and one's status could be legally altered. I have no knowledge at present about how often such things happened in the Philippines. Nor do I know by what means a Chinese mestizo, if he so desired, might be registered as a Chinese, or how a non-mestizo could achieve mestizo status. Given the prestige of the Chinese mestizos it is likely that there were many non-mestizos who sought such status. On the other hand, the Rizal example notwithstanding, it is doubtful that there were many instances in which mestizos attempted to alter their classification. ${ }^{11}$ The position of the mestizos was, in many ways, a favorable one.

It needs to be emphasized here that the legal distinctions spoken of were also social distinctions. The Spanish government followed a policy of social division. But the result could never be a rigidlydefined "plural society". Mobility between groups was possible for individuals and families, by legal action, as suggested above, or, more commonly, by intermarriage. The basis for intermarriage was that both parties be Catholic. It is the presence of Catholicism, and Spain's emphasis upon propagating it, that distinguish Spanish Philippine social policy from that of other colonial countries in Southeast Asia. Spanish social policy was one of social division mitigated by cultural indoctrination, centering upon Catholicism, which was available to all elements in society. The result was that the various fragments of Philippine society could not only meet in the marketplace; they could alsa meet in the church.

9. Austin Craig, Rizal's Life and Minor Writing; (Manila, 1927), pp. 7-23.

11. A brief outline of this procedure, with references, is found in J. F. King, "The Case of José Ponciano de Ayarza: A Document on Gracias al Sacar," Hispanic American Hislorical Review, XXXI, No. 4 (Nov. 1951).

11. I am aware of only one case of a mestizo formally requesting transfer to Chinese status. Sec Comenge, p. 229. 


\section{THE CHINESE MESTIZO IN PHILIPPINES}

Given the legal distinctions and problems of personal identification mentioned above, what was the popular distinction of the term mestizo? By the nineteenth century, the Chinese mestizos had become so numerous and their influence so great that the term "mestizo", as popularly used in the Philippines, meant "Chinese mestizo". This point is made by Retana, in his Diccionario de filipinismos, again in testimony before the U.S. Philippine Commis: sion, and (naturally enough) by the Chinese mestizos themselves. ${ }^{12}$ This explicit definition of "mestizo" as "Chinese mestizo" was implicitly opposed by James LeRoy, an acute, if not always accurate American observer of the Philippine scene. LeRoy argued that Spanish mestizos were of predominant importance in the late nineteenth century, and scarcely mentioned the Chinese mestizos. ${ }^{13}$ Apparently, LeRoy chose to believe that in popular usage the term "mestizo" referred to Spanish mestizos, or else he did not concern himself with popular usage. Perhaps he simply assumed that, logically, those enjoying fortune and power were most apt to be descendants of the conquerors and rulers. Whatever the reason, LeRoy was, I believe, in error, and I shall now attempt to demonstrate why I think so.

The development of a Chinese mestizo group in the Philippines can be understood only by first considering briefly certain features of the history of the Chinese in the Philippines. Soon after the Spaniards arrived, the Chinese moved into an important economic position. Chinese merchants carried on a rich trade between $\mathrm{Ma}$ nila and the China coast and distributed the imports from China into the area of Central Luzon, to the immediate north of Manila. Chinese established themselves at or near Spanish settlements, serving them in various ways: as provisioners of food, as retail traders, and as artisans. Because the Chinese quickly monopolized such activities, the Spanisin came to believe their services indispensable. But just as quickly there developed mutual feelings of distrust and animosity between Chinese and Spaniard; cultural differences seemed too great to be bridged. In the early years of Spanish rule in the Philippines open hostilities were frequent. The Spanish dilemma was quickly apparent: unable to live without the Chinese,

12. W. E. Retnna, Diccionario de filipinismos (New York; Paris 1921), p. 12\%; United States Philippine Commission, 1899-1900, Report of the Philippine Commission to the President (4 vols; Washington, 1900-01), II, p. 179; PNA, Gremios, 16-5-5.

13. James A. LeRoy, The Americans in the Philippines (2 vols; Boston, New York, 1914), passim. See also his Philippine Life in Town and Country (New York, London, 1905), esp. pp. 35-38. LeRoy mentions "half-caste caciques" and also speaks of "mestizo plantation owners" in Batangas and Pampanga, but does not further identify them. See Philippine Life, p. 186, and Americans, I, p. 10 . 


\section{THE CHINESE MESTIZO IN PHILIPPINES}

they were equally unable to live with them. The Chinese population was many times larger than that of the Spanish, further inciting Spanish fears of Chinese revolts. The result was a compromise in Spanish policy between economic interest and political security. Early in the Spanish period laws were passed limiting the number of Chinese who could reside in the Philippines and restricting their areas of settlement. But - at least until the mid-eighteenth century - such laws were often enforced in a very loose manner. ${ }^{1+}$

Given the Spanish assumption that the Chinese were economically indispensable (and few Spaniards questioned the assumption during the first centuries of Spanish rule), the only way to overcome the dilemma would be to find means to convert the Chinese to Catholicism and Hispanism. This is not to say that efforts to convert the Chinese were entirely a matter of studied policy whose objectives were to "tame" those who controlled so much of the colony's economic life. The Spanish priests in the Philippines had other reasons for wishing to work among the Chinese. One of these was related to their desire to open up and develop the China mission field. It was hoped that work among the Philippine Chinese might help bring this about. ${ }^{15} \mathrm{~A}$ more basic reason was simply that the Chinese were there, and that the Spanish mandate to Catholicize and Hispanize the people of the Philippines seemed to mean all the people in the Philippines. Nevertheless, the creation of a dependable group of Catholic Chinese merchants and artisans loyal to Spain would be a clear advantage. Economic interest and political security could thus be harmonized.

Spanish policy thus included attempts to convert the Chinese, sometimes making use of such inducements as reduced taxes and fewer restrictions on travel and residence for those who accepted the Faith. ${ }^{16}$ But an even better method of "taming" and perhaps assimilating the Chinese was conversion followed by marriage and permanent settlement in the Philippines. There being no Chinese women in the Philippines, "marriage" meant "intermarriage" with indias. Informal unions between Chinese and indias were common. There would have been a sizeable mestizo population regardless of Spanish policy. But the fact that marriages between Chinese

14. More detailed discussion is found in my unpublished dissertation, The Chinese in Philippine Economy and Society, 1850-1898 (University of California, Berkeley, 1961), Part I.

15. BR, X, p. 251; Archivo del bibliófllo filipino, ed. W. E. Retana (5 vols; Madrid, 1895-1905), III, p. 55; T. H. Pardo de Tavera, Una memoria de Anda y Salazar (Manila, 1899), p. 23; Berriz, Anuario 1888, I, p. 567.

16. Recopilación, libro 6, título 18, ley 8, Charles H. Cunningham, The Audiencia in the Spanish Colonies as Illustrated by the Audiencial of Manila (Berkeley, 1919), p. 378. 


\section{THE CHINESE MESTIZO IN PHILIPPINES}

and indias, when both partners were Catholics, were legally recognized and encouraged resulted in the creation of special cominunities of mestizo. The most important of these was the Binondo community, across the river from the walled city of Manila.

Binondo was founded as a Chinese town in 1594. A royal order for the expulsion of all Chinese from the Philippines had been received. But Governor Dasmarinas realized that the city of Manila, the largest Spanish settlement, needed to retain at least a small number of Chinese for its economic services. Therefore he purchased a tract of land across the river from the walled city and gave it to a group of prominent Chinese merchants and artisans as the basis for a new Chinese settlement. Since the existing Chinese settlement near Manila, the Parian, was supposed to be evacuated, the establishment of Binondo was intended to be a means of formally obeying the royal order while insuring the availability of goods and services provided by the Chinese. In the beginning, religious and cultural questions were not involved. ${ }^{17}$

But the missionary enterprise of Spanish Dominican fathers soon made of Binondo a kind of acculturation laboratory. Once Binondo had been assigned them as a parish, the Dominicans quickly made of it a community of married Catholic Chinese. NonCatholics in areas around Binondo were proselytized, baptized, married, and added to the community of married Catholics. By 1600 this group had reached a size of perhaps five hundred or more. ${ }^{18}$ The first generation of mestizo offspring had also appeared, and there were high hopes that they would excel in higher education and assist the Dominicans in the spiritual conquest of China. ${ }^{19}$

Thus, almost from the first, Binondo was a separate, Catholic, Chinese and mestizo community, with certain special privileges. The Chinese had founded Binondo on the basis of Dasmarinas' land grant, which was given in perpetuity, to be tax free, and inalienable to non-Chinese and non-mestizos. The grant was accompanied by limited self-governing privileges. ${ }^{20}$ The Community of Christian Chinese and Mestizos, as it was called in the seventeenth century, was repeatedly confirmed in its communal possession of the land on which Binondo stood, all counter-claims were rejected, and the Community recognized as sole proprietor of the area, with

17. The text of Dasmarinas' "donation" is found in PNA, Gremios, 16-5-5. Compare Jesús Gayo, O.P., "Ensayo histórico-bibliográfico," Doctrina Christiana; Primer libro impreso en Filipinas (Manila, 1951), p. 70.

18. Antonio de Morga, Sucesos de las Islas Filipinas, ed! W. E. Retana, (Madrid, 1910), p. 225; BR, XVII, p. 216. Gayo (p. 73) gives 800.

19. Gayo, pp. 72-73.

20. PNA, Gremios, 16-5-5. 


\section{THE CHINESE MESTIZO IN PHILIPPINES}

the right to collect rent from any non-members who settled therein. ${ }^{21}$

Clearly, Binondo, by the seventeenth century, was intended to be a settlement for Catholic Chinese and their mestizo descendants, and ultimately, in the continued absence of Chinese women, an all-mestizo community. Subsequently, however, indios began to settle in Binondo. The eventual result was the formation of separate communities of Chinese, mestizos, and indios within Binondo.

At first, when their numbers were small, the mestizos sided with the Chinese against the indios in a contest for political and social supremacy in Binondo. In 1687 the mestizos and Chinese formally organized the Community of Chinese and Mestizos of Binondo, a kind of combined municipal corporation and religious sodality, whose principalia of about fifty persons elected ten Chinese and ten mestizos as a corporate council. ${ }^{22}$ Later as the mestizos became the leading element in Binondo, they broke away from the Chinese, forming their own Gremio de Mestizos de Binondo in 1741..23 There were now three gremios in Binondo, each claiming superiority in civil and ceremonial affairs within the town. The mestizos, during the next century, made good their claim. In so doing, they won the right to rule in matters concerning the common welfare. That is, besides holding authority over matters relating to its own group, as each gremio did, the mestizo gremio had jurisdiction over affairs of general concern. It was still, of course, subject to the authority of the provincial governor.

While this was going on in Binondo, the Jesuits had established a similar "reduction", or mission settlement, of Catholic Chinese in Santa Cruz, adjacent to Binondo. Little is known about the history of this community, except that the three-gremio arrangement that developed in Binondo occurred in Santa Cruz as well by $1741 .{ }^{24}$

The three-gremio situation of Binondo and Santa Cruz appears to have been unusual. More common, in areas where there were mestizos, were two-gremio towns, in which a mestizo population, left behind by a since-receded wave of Chinese immigration to that area, formed a gremio alongside an indio gremio. Through-

21. Ibid. See also Gayo, pp. 27, 90.

22. PNA, Gremios, 16-5-5.

23. Ibid. The term gremio in the Philippines had a range of meaning from a religious sodality to a craft gild. At times it was applied to almost any kind of group.

24. See BR, XXIX, pp. 102-03. 


\section{THE CHINESE MESTIZO IN PHILIPPINES}

out most of the Spanish period, Chinese settlement in areas away from Manila was sporadic and discontinuous enough so that the usual situation was a mestizo residue which, if sufficiently numerous and self-consciously mestizo, organized itself into a mestizo gremio. The Chinese gremios were found only in Binondo and Santa Cruz, and there only because Manila, as the largest settlement and the port of debarkation for immigrants, was the focal point of Chinese immigration, and the one place in the Philippines to which the Chinese might usually come - whatever other restrictions on settlement there might be. Hence, the Binondo and Santa Cruz Chinese gremios were replenished; the Chinese settlements away from Manila erratically so, if at all.

\section{II. $1741-1850$}

By 1741 the Chinese mestizos had been recognized as a distinct element in Philippine society, sufficiently numerous to be organized and classified separately. From this time date the separate tax classification and the mestizo gremios. ${ }^{25}$ At this time, too, we begin to hear comments about the mestizos as a group. Padre Murillo Velarde complains: "now we have a querulous group of mestizo" who could cause discord in society. ${ }^{26}$

If the mestizos were numerous enough to be separately organized, how numerous were they? Comprehensive data for the 1740's are unavailable. ${ }^{27}$ We must look to the period around 1800 for our first statistics. Comyn, writing around 1810, gives the following figures ${ }^{28}$ :

25 PNA, Gremios, 16-5-5; "List of Gobernadorcillos of Mestizos of Santa Cruz, 1741-1889," Philippine Historical Review, I, No. 4 (Aug. 1905), No. 5 (Sept. 1905).

26. Quoted in John Foreman, The Philippine Islands (2nd ed; New York, 1899), p. 214.

27. We do have some 1738 data for one province, Pampanga, in Central Luzon, which was said have 870 mestizo tribute-payers and 9275 indio tribute-payers. Joaquin Martínez de Zúñiga, O.S.A., Estadismo de las Islas Filipinas, ed. W, E, Retana (2 vols; Madrid, 1893), I, p. 460. If each tribute-payer represented about 6.5 persons, there may have been over 5,000 mestizos in a population of over 65,000. In other words, the mestizos made up perhaps seven or eight percent of the Pampanga population.

28. Comyn, p. 186. The appearance of fractional figures is due to the use of the factor 6.5 as representing the number of persons per tribute. The figures given here were derived by multiplying the number of tributes for each province by 6.5. Note that sometimes two provinces are represented as having exactly the same number of indios or mestizos. Note also the round numbers for Zamboanga. Clearly, these figures can give us only a general impression of the population. 


\section{THE CHINESE MESTIZO IN PHILIPPINES}

\begin{tabular}{lcc} 
Province & Indios & Mestizos \\
\cline { 2 - 3 } Albay & 103,935 & $2,398.5$ \\
Antique & 39,325 & - \\
Bataan & 23,985 & $5,596.5$ \\
Batangas & 127,920 & $3,997.5$ \\
Bulacan & 143,910 & $20,037.5$ \\
Cagayan & 76,752 & 162.5 \\
Calamianes & 15,990 & - \\
Camarines & 159,900 & $2,398.5$ \\
Capiz & $87,145.5$ & 396.5 \\
Caraga & 19,183 & - \\
Cavite & 51,967 & $7,195.5$ \\
Cebu & 151,905 & 4,797 \\
Ilocos & 361,270 & 4,797 \\
Iloilo & 167,895 & 1,599 \\
Laguna & 95,940 & 3,198 \\
Leyte & $68,007.5$ & 306.5 \\
Mindoro & 13,169 & - \\
Misamis & $18,388.5$ & - \\
Negros & 41,574 & 799.5 \\
Nueva Ecija & 9,750 & - \\
Pampanga & 127,920 & $20,957.5$ \\
Pangasinan & 159,900 & $3,997.5$ \\
Samar & 88,595 & 791.5 \\
Tayabas & 71,955 & 162.5 \\
Tondo & 143,910 & $35,077.5$ \\
Zambales & 23,985 & 474.5 \\
Zamboanga & 1,500 & 500 \\
\hline & $-120,621$ \\
\hline & $2,395,676.5$ &
\end{tabular}

Adding together these two totals, some 4,000 "blancos" (Spaniards and Spanish mestizo), and some 7,000 Chinese, gives a total Philippine population of 2,527,298. The Chinese mestizo total of 120,621 represents about five percent of the total population. Zúñiga's population material for 1800 , and some data of 1791 referred to by Comyn show figures considerably less in absolute terms than those given here, which could mean either a considerable population growth in the first decade of the nineteenth century, or else substantial errors in some of the calculations. But regardless of the absolute figures, the mestizo percentage of the total and the 


\section{THE CHINESE MESTIZO IN PHILIPPINES}

mestizo geographical distribution are about the same as those given above. ${ }^{29}$

Although the mestizo total represented only about five percent of the Philippine population as a whole, there were areas of mestizo concentration in which they formed a much larger perrentage of the regional population. Looking at the figures above from the standpoint of geographical distribution, the most obvious feature is the mestizo numerical strength in the three Central Luzon provinces of Tondo, Bulacan, and Pampanga. Over sixty percent of the mestizos in the Philippines resided in these three provinces. The province of Tondo alone accounted for almost thirty percent of the mestizo population in the Philippines. And although these were heavily populated provinces, the number of mestizos relative to the total population was not insignificant. In Tondo, mestizos made up about fifteen percent of the population; in Bulacan and Pampanga they accounted for about eleven percent each. In other, less-populated provinces within the same general region of Central Luzon, the mestizos, although not numerous in absolute terms, were an important percentage of the provincial population. In Bataan fifteen percent of the population was mestizo. Twelve percent of Cavite's population was mestizo.

But away from Central Luzon there were no large concentrations of mestizo. In other parts of Luzon there were mestizos-some in almost every province. But in the Visayas and Mindanao, mestizos were few, both in absolute terms and relative to the local population. Indeed, something like ninety percent of the mestizos in the Philippines lived in Luzon, and only in a few spots in the other islands - notably the provinces of Cebu, Iloilo, Samar, and Capiz, were mestizos of any significance.

This pattern of mestizo geographical distribution may be at least partly explained by reference to the pattern of Chinese settlement. The province of Tondo included the northern part of what is today the city of Manila, including Binondo and Santa Cruz, as well as the modern province of Rizal. Manila was always the port-of-entry for new arrivals from China; many never went beyond it. Spanish laws frequently restricted the area in which Chinese might, reside to Manila, and its environs. Furthermore, since the middle of the eighteenth century the functions of the old Parian had been shifted to a new ghetto, the Alcaicería de San Fernando, located in Binondo, thus making Binondo no longer the segregated

29. Comyn, pp. 187, 201, Zúñiga, I, 150, 194, 306, 461, 539; II, pp. 9, 20, 25, $31,40,47,53,62,67,70,77,81,88,93,96,100,103,110,113$. 


\section{THE CHINESE MESTIZO IN PHILIPPINES}

settlement of Catholic Chinese and mestizos it had been in the seventeenth century, but a great Chinese and mestizo town in which permanently-residing Catholic Chinese and mestizos rubbed shoulders with newcomers from China. ${ }^{30}$ Beyond Binondo stretched the suburban towns to which Chinese could usually migrate, however strict the government's policies. When residence restrictions were eased, the natural avenues of expansion were those of the trade routes that linked Manila and the Manila Bay perimeter with the Central Luzon plains. The pattern of Central Luzon settlement by the Chinese is therefore not surprising, and the pattern of mestizo distribution in this area may largcly be explained as a consequence of Chinese sectlement patterns. On the other hand, one should note that since the mestizos were relatively free to move about, their areas of residence were not entirely predetermined by where their paternal ancestors had lived. Nevertheless, mestizos were found usually in those areas where Spanish settlement had created economic: opportunities, and in this they were like their Chinese ancestors. ${ }^{31}$ Thus, the largest bodies of mestizos in the Visayas were those around Cebu City and in the province of Cebu. Cebu City, the earliest Spanish settlement in the Philippines, had been the site of a parian second only to that of Manila. Other important mestizo communities were those of the Jaro and Molo area of Iloilo-again a region of early Spanish settlement.

Turning from the size and distribution of the mestizo population about 1800 to its occupational characteristics, we find the mestizos of that time primarily engaged in landholding and wholesale trading, although there were also mestizos in the professions, including the small but growing native clergy. Spanish writers during the early decades of the nineteenth century especially noted the landholding and wholesaling activities - and the wealth - of the mestizos of Central Luzon. Zúñiga, in particular, repeatedly points out the role of the Central Luzon mestizos as lessees (inquilinos) of rice-producing lands. Some of the lands in question were subiet by the inquilinos for amounts in excess of the rent owed by the inquilino to the landowner. Others were worked according to the kasamahan system, by which the actual tiller received a percentage of the crop, the inquilino taking the rest, from which he paid his rent. ${ }^{32}$ For instance, at the Augustinian-owned hacienda

30. Wickberg, The Chinese, p. 21.

31. Wickberg, "Early Chinese Economic Influence in the Philippines, 1850-1898", Pacific Affairs, XXXV, No. 3 (Fall 1962), p. 277; Zúñiga, I, pp. 44ff, 306, 334-35, 460, 539; II, pp. 20-203; Juan Delgado, S.J., Historia sacro-profana, política y natural de las Islas del Poniente llamadas Filipinas (Manila, 1892), pp. 27-46; Comyn, p. 186.

32. Zúñiga, I, 45-48, 334-35, 398. 


\section{THE CHINESE MESTIZO IN PHILIPPINES}

of Pasay the inquilinos, according to Zúñiga, amounted to about 4,000 , of whom about half were Chinese mestizos,

a people who are richer than the indios and who spend more, not only on food, but also on dress, gaming, tobacco, wine, and vices. They have no other source of income than the land, since their trading is minor and their manufacturing nil. ${ }^{33}$

Again, at Biñan, in Laguna, Zúñiga notes that the best houses were those of Chinese who had settled and married there or of Chinese mestizos.

who are those that compose the principalia of this town. The sole line of business that has enriched these people and has attracted so many Chinese to that town is rice, which is harvested in great abundance ....34

The Biñan hacienda, Zúñiga says, is "mostly in the power of the rich", who work it by means of the kasamahan system. The mestizos of Biñan had also acquired by purchase the lands of the people of Cabuyao, who were now working as tenants on lands they had once owned. Zúñiga argues that the alienation of indio lands to mestizos is in part the result of excessive litigation over land ownership, which impoverishes the indios, who then sell their land rights to the mestizos. He concludes: "If no remedy is found, within a short time the lords of the entire Archipelago will be the Chinese mestizos." 35

To the immediate north of Manila, the rich people of the towns of Tondo, Tambobong (Malabon), Polo, Ovando, Meycauayan, and Bocaue - principally mestizos - were inquilinos of estates in the Caloocan area. These mestizo inquilinos, unlike those of Pasay and Biñan, had more than one source of income. Living in their imposing houses in the towns, they combined inquilino income from the kasamahan system with profits from middle-man trading between Manila and the Pampanga-Bulacan area. These towns were located on the water routes connecting Manila's markets with the produce areas of the Central Plains to the north. The mestizos of these towns carried on a lucrative commerce by collecting goods from the north and bringing them into Manila for sale. Sometimes, non-perishable goods, such as rice and salt, were stored by the mestizos in their own warehouses until the market price had risen before bringing them into Manila. ${ }^{36}$

33. Ibid., I, p. 12. Unless otherwise noted, all translations are my own.

34. Ibid., I, pp. 44-45.

35. Ibid., I, pp. 48-51.

36. Ibid., I, p. 296, 334-35, 348-49. 


\section{THE CHINESE MESTIZO IN PHILIPPINES}

Tambobong (Malabon), a half-mestizo, half-indio town of some 15,000 population, had sprung from obscurity because of its position as a center for transshipment of goods from Pampanga and Bulacan to Manila. Some Tambobong mestizos were worth, according to Zúñiga, as much as 40,000 pesos. ${ }^{37}$ Polo, with a population of about 1,000 had an important mestizo minority, forming its wealth. iest element. The people of Polo specialized in the collection of rice for transport to Manila. Nearby Ovando was much the same. Meycauayan specialized in stoneworking, but, according to Zúniga, most of the profits went not to the indio workers but to the mestizos of that town who loaned tools and advanced money at high rates of interest to the stone-cutters. ${ }^{38}$

East of Manila the rich town of Pasig which controlled the gateway from Manila upriver to the province of Laguna, specialized in wholesale and retail trade. Goods imported from abroad were purchased at Spanish-owned warehouses in Manila by the Chinese and Chinese mestizos of Pasig, who then controlled their distribution between Manila and Laguna. They also sold produce of their area to Manila Spaniards for export abroad. One of the most imepressive buildings in Pasig was the stone casa real of the mestizo gremio. Nearby was an hacienda owned by a mestizo. ${ }^{39}$

Zúñiga particularly notes a pattern of mestizo money-lending and acquisition of indio lands in Bulacan. The classic instrument of land alienation was the pacto de retro, or contract of retrocession, by which the indio landowner pawned his land for ready cash with an option to "repurchase" it at a price equal to the amount of the loan. Since the indio could seldom repay the loan and redeem the land the land went by default to the mestizo. In this fashion, by providing loans for the expenses of fiestas, baptisms, and litigation, the mestizos - and some rich indios - were acquiring indio lands, a process which Zúñiga generalizes about for the whole archipelago. ${ }^{40}$ As an example, he cites Bulacan, where the mestizos of Bigaa, San Isidro, Bocaue, Polo and Meycauayan had become owners of some of the best rice-producing lands through use of the pacto de retro. Zúniga, alarmed, calls on the Spanish government to stop this practice lest the mestizos become lords of the archipelago, "from which may be anticipated many adverse consequences." 41

37. Ibid., I, pp. 296, 335.

38. Ibid., I, pp. 348-50, 353.

39. Ibid., I, pp. 204, 206, 272.

40 Ibid., I, pp 364-65, 398, 440, 492-93. See also, 50-51.

41. Ibid., I, pp. 364, 367, 395, 398, 440, 457. 


\section{THE CHINESE MESTIZO IN PHILIPPINES}

It is clear that the Spanish administration was concerned about the land alienation problem. As early as 1768 there were laws against the use of the pacto de retro-specifically, against its use bv the Chinese and the Chinese mestizos. ${ }^{42}$ But it was not easy to break the power of the Chinese and mestizo money-lender. In the indigo industry, for instance, Spaniards attempted to replace the mestizo moneylenders by advancing money to growers. But this was a shortlived experiment. The mestizos, unlike the Spaniards, lived close to the indios, knew their language, and watched the harvest closely. Spaniards from Manila had difficulty challenging their monopoly.

Moreover, the power of some mestizos was becoming such that when their interests were threatened by government planning they involved the government in legal action, claiming that what the government proposed would harm the indio, whom they wished to protect. Finally, the government representatives simply gave in to the mestizos' wishes. ${ }^{43}$

To generalize, reading Zúñiga one sees a picture of rising mestizo economic power in Central Luzon, challenging the economic position of the provincial governors, who enjoyed trading privileges as an official perquisite, and, ultimately, calling into question even the local political power of both the governors and the local Spanish priests. The latter two, thought Zúniga, were the only local forces potentially able to check the growing power of the mestizo and his exploitation of the indio.

Yet even Zúñiga had to admit the enterprising nature of the mestizos of Central Luzon. The indigo industry in the Philippines, just referred to, was developed largely through mestizo and Chinese enterprise. It began with the mestizos of Tambobong (Malabon), who were taught an indigo manufacturing method by an Augustinian priest. They chose the province of Bataan to experiment with the new process. There they financed the growers, processed their product, and sold it to Chinese in Manila, making handsome profits. In this way, mestizo enterprise from one province helped develop a new product in another. ${ }^{44}$

In another way mestizo enterprise showed itself - or attempted to do so. The provision of meat for certain local communities

42. BR, L, p. 241; Berriz, Anuario 18s8, I, p. 591; "Contratos usurarios," Revista general de legislurión y jurisprudencia, XXV (Madrid, 1864), p. 176.

43. Zúñiga, I, pp. 368-70; 404-05.

44. Ibid., 1, pp. 493-94. Sce also pp. 404-05 for mestizo indigo purchasing in Bulacan Some years later, del Pan noted that most of the lands in Bataan had been acquired by people from Malabon and Pampanga. Del Pan, Las Islas Filipinas, p. 365. 


\section{THE CHINESE MESTIZO IN PHILIPPINES}

was difficult to handle, and mestizos in these areas sought to contract with the government to supply it. But the provincial governors opposed this or else allowed it but harassed the mestizos to the point that the latter abandoned the contracts. ${ }^{45}$

Likewise, in discussing the mestizos in the Visayas, Zúñiga cannot help admitting their value in terms of economic prosperity. Here he adopts an attitude similar to the ambivalence with which the Spanish usually regarded the Chinese. After mentioning the importance of the mestizos to the prosperity of Samar, he notes their absence in Antique and says:

and this is unfortunate, because although mestizos are somewhat prejudicial to towns in some places, they have their usefulness.

In Antique, the provincial governor bought up the rice of the indios, and the mestizos of other provinces went there to buy it.

If there were mestizos [in Antique], they would buy the rice, and store it for profitable sale to the indios of the country, or loan it to them at usurious rates, which, although bad, is better than their dying of hunger. ${ }^{46}$

Zúñiga has nothing specific to say about mestizo landholding in the Visayas, an area with which he was less familiar than he was with Luzon. It is likely that mestizo activities in the Visayas were primarily those of wholesale trading between the islands. In Luzon, on the other hand, as noted above, some mestizos were wholesalers of goods between Manila and the nearby provinces, but others might be either lessees of land or actual landowners. Still others might combine landholding with trading.

Mestizos were also entering the native secular clergy, which was beginning to take over some curacies from the Spanish regulars. There were Spaniards who viewed this with disgust and alarm. Comyn, writing in 1810 , claimed that entire provinces were being transferred to indio and mestizo clergy, to the detriment of their parishioners, who could not but be disgusted at the ignorance, tyranny, and impropriety of the native clergy. ${ }^{41}$ Bernaldez Pizarro, a Spanish regular, writing in 1827, also deplored the growing influence of the native indio and mestizo secular clergy. ${ }^{48}$

총. Zliniga, I p. 440

46. Tbid., II, p. 100 .

47. Comyrs, p. 153.

48. BR, LI, pp 203-06. For the size of the secular clergy see Comyn, p. 159 and $B R, L, p .39$. On educational opportunities for mestizos and indios and the mestizo response thereto see BR, XIV, pp. 121-230; San Pedro, II, p. 523 . 


\section{THE CHINESE MESTIZO IN PHILIPPINES}

Comyn, like Zúñiga, has much to say about both the qualities and the activities of the mestizos.

There is also a kind of trade peculiar to the rich indios and Chinese mestizos, an industrious caste, and one that is master of most of the wealth, which consists of advance buying of the harvests of indigo, sugar, rice, etc., with a view to profiting from the resale of these products to the retailer. ${ }^{49}$ In the case of Chinese mestizos economy and cupidity go together with intelligence and energy to increase their funds, and, scattered through the principal towns of the islands, they are found in possession of the best lands and the most lucrative internal trading. There is excellent reason to predict that this industrious and knowledgeable people will be able, little by little, to draw to itself a mass of money of very great significance, although it is impossible to determine how much or to what destination it may ultimately go. ${ }^{50}$

Because the Spaniards had concentrated on foreign trade to the neglect of internal trade, by Comyn's time

the entire internal trade is monopolized by indios principales, Chinese mestizos of both sexes, and a few Chinese. ${ }^{51}$

Although Comyn understates the extent of Spanish involvement in internal trade by ignoring the provincial governors' share of it, this statement of his serves to underline the increasing participation of enterprising natives - especially mestizos.

By the middle of the nineteenth century the position of the Chinese mestizo in Philippine economy and society was firmly established, as a consequence of developments during the century 1750-1850. From the vantage point of 1850 let us take a long look at the mestizo of that time.

The total population of the Philippines, by the mid-nineteenth century, was something in excess of 4,000,000 - perhaps as high as $5,000,000.52$ The mestizo population was estimated by one source to be $240,000 .^{53}$ Thus, the mestizos apparently continued to form about five to six percent of the total Philippine population.

But while their relative numbers had not increased, there were

49. Comyn, p. 50.

50. Ibid., p. 59.

51. Ibid., p. 56 .

52. Jean Mallat de Bassilan, Les Philippines (2 vols; Paris, 1846), I, p. 97; Sir John Bowring, $A$ Visit to the Philippine Islands (London, 1859), p. 111, The official figure derived from the 1877 census was $5,567,685$. Josè Jimeno Agius, Población y comercio de las Islas Filipinas (Marid, 1884), p. 10.

53. Mallat, I, p. 97. Sinibaldo de Mas estimated there were "over 200,000". BR, LII, p. 39. 


\section{THE CHINESE MESTIZO IN PHILIPPINES}

some interesting changes in their geographic distribution. As before, about thirty percent of the mestizos were residents of the province of Tondo. In Central Luzon generally, mestizos continued to be numerous. But now we begin to notice mestizos pushing farther into Luzon - into Abra, and especially into Nueva Ecija. In the latter province, by mid-century, mestizos were as numerous as they were in Bataan, Batangas, and Ilocos Sur. In the Visayas, the largest group of mestizos, as before, was that in Cebu. Iloilo and Samar also remained centers of mestizo influence. But now we find a few mestizos in Antique, and, most interesting of all, for the first time we notice mestizos in Mindanao - in the eastern part of the island (Caraga province), and in Misamis. ${ }^{54}$

The mestizo population of about 240,000 was part of a Philippine population that included an estimated 3,700,000 lowland indios, anotker 1,025,000 mountain people who had not submitted to Spanish rule, 20,000 Spanish mestizos, 5,000 Spaniards, and 10,000 Chinese. ${ }^{55}$

By the middle of the nineteenth century the economic position of the Chinese mestizos was stronger than ever. Not only did they have substantial land interests, but they were well on the way to monopolizing internal trading, with only the provincial governors as their competitors.

Lannoy, writing in the 1840's, said that despite the attempts of the Spanish to treat them with disdain, it was the Chinese mestizos who had the biggest fortunes in the Philippines. ${ }^{56}$

Other observers commented on the wealth and economic influence of the mestizos. Sinibaldo de Mas, in his report of 1842 , said:

Almost all the retail commerce is in their hands and they may be counted the middle class of the Philippines.

They are the proprietors, merchants, and educated people of the country and will dominate public opinion.

The Chinese mestizos will, within a century, have grown to at least one million by natural increase and immigration from China, and will possess the greater part of the wealth of the Islands. ${ }^{57}$

Zamora, writing in the 1840 's, predicted that the Chinese mestizos

54. Rafael Díaz Arenas, Memorias históricas y estadísticas de Filipinas (Manila, 1850), cuaderno 5. Díaz Arenas gives no data for Leyte.

55. Mallat, I, p. 97.

56. J. Lainnoy, Iles Philippines (Bruxelles, 1849), p. 113.

57. BR, LII, pp. 64-65. 


\section{THE CHINESE MESTIZO IN PHILIPPINES}

would completely replace the Chinese, economically.58 And Sir John Bowring equated mestizaje and progress, arguing that the relative backwardness of Mindanao and some other areas could be explained by the absence of mestizos, whom he described as a "great improvement upon the pure Malay or Indian breed." 59

In the city of Manila, foreign traders who wished to distribute imported goods worked through the mestizos of that city. As for Manila's retail commerce, it was handled exclusively by Chinese mestizos and Chinese. They also had the majority of artisan's shops and were active in urban wholesaling. ${ }^{60}$

Landholding continued to be an important source of mestizo income. According to Mallat, who was in the Philippines about 1840 , the largest landholders in Luzon were the religious orders. But the next largest were the Chinese mestizos. whom he spoke of as rich, energetic, and economical. Like Zúñiga, Mallat was critical of the mestizo landholders of Central Luzon. He claimed that they treated the indios harshly, giving them little money or food, and making them work hard. Their motto, Mallat thought, was "bread in one hand, the stick in the other." 61

In Central Luzon the mestizo influence was indeed strong. By the 1840's a number of towns had reached a size of from 10,000 to 40,000 persons. Among these were several whose leading elements were Chinese mestizos, such as Tambobong, Malolos, Biñan, and Binondo. ${ }^{62}$ Mallat noted the presence of many rich mestizo sugar mill owners in the town of Bulacan. In Pagsanjan, the capital of Laguna province, most of the residents were mestizos, and the lands nearby all belonged to them. Moreover, these mestizos did practically all the business at the weekly market in the town of Santa Cruz. ${ }^{63}$

Sir John Bowring, who visited the Philippines during the 1850's, observed that in the towns around Manila "almost every pueblo has some dwellings larger and better than the rest, occupied by

58. José María Zamora y Coronado, Biblioteca de la legislación ultramarina en forma alfabética (7 vols; Madrid, 1844-46), VI, p. 103.

59. Bowring, pp. $340,344-45,350-51$.

60. Mallat, I, pp, 171, 184; II, pp. 138, 320.

61. Ibid., II, pp. 365-66. Jagor noted the extension to Camarines of mestizo land acquisitions by mortgage foreclosures. "Some mestizos possess several pieces of ground; but they are seldom connected together, as they generally acquire them as mortgages for sums bearing but a small proportion to their real value." Feador, Jagor, Travels in the Philippines (London, 1875), p. 156.

62. BR, LI, p. 199; Mallat, I, pp. 98, 182, 188. The town of Taal, which had reached quite a considerable size, was regarded as a kind of exception to the general Central Luzon rule in that it had no mestizos. Del Pan, Las Islas Filipinas, p. 371.

63. Mallat, I, pp. 189, 245. 


\section{THE CHINESE MESTIZO IN PHILIPPINES}

the native authorities or the mixed races (mostly, however, of Chinese descent) ..." In general, Bowring cited the mestizos as being the most industrious, persevering, and economical element in the Philippine population. "The great majority of the merchants and landed proprietors belong to this class, and most of the subordinate offices of government are filled by them." 64

In the writings of the mid-nineteenth century we now begin to find more comments about the mestizo in interisland trade, especially in the Visayas. The centers of interisland trading, besides Manila, were Cebu, and the twin settlements of Molo and Jaro in Iloilo. The mestizos of Cebu, Molo, and Jaro carried on an important trade, collecting raw materials in the Visayas and transporting them to Manila where they sold them to Chinese or European merchants for export overseas. In Manila they purchased imported manufactures which they took back with them for distribution throughout the Visayas. ${ }^{65}$ Mestizo purchases of raw materials for export were carried out in a rather haphazard manner. Bernaldez Pizarro, deploring the "oppressive rule of the mestizo trader" over the indio, remarks:

the agriculture of Filipinas at this time depends on the irregular and transient stimulus which is furnished to it by the peripatetic capital of the mestizo, who buys only in the years when he calculates that he must in view of the condition of the crops and the market, make a profit . . . . ${ }^{\text {b0 }}$

It was the mestizos who made Cebu wealthy. From Cebu the mestizos'sent their purchasing agents eastward to Leyte and Samar, southward to Caraga and Misamis, and westward to Negros and Panay to buy up local products for sale to foreign merchants in Manila. In Leyte and Panay they bought up tobacco, sea slugs, and mother-of-pearl; in Samar, they purchased cacao, coconut oil, and tobacco: Caraga and Misamis sold them gold, and in Misamis they also bought coffee, wax, and cacao. Cacao was also purchased in Negros, as were rice, pearls, fish, wax and other products. ${ }^{67}$

In Cebu City there was a particularly important group of mestizos, apparently descendants of the Chinese inhabitants of that city's parian. These mestizos, a few thousand in number, continued to live apart from the city in the Parian, where they had a

64. Bowring, pp. 113-14.

65. Mallat, I, pp. 311-20; PNA, Provincial Documents, legajo 117, número 4; Bowring, pp. 114, 359-403.

66. BR, I.I, p. 245.

67. Mallat, I, pp. 311-20. Mallat also notes that the internal trade of Samar was controlled by the mestizos of that island. ibid., I, pp. 290-91. 


\section{THE CHINESE MESTIZO IN PHILIPPINES}

priest of their own at royal expense ${ }^{68}$ They were rich, industrious, and active. Buzeta and Bravo go so far as to say that the City of Cebu could not even have survived without them. ${ }^{69}$

Molo and Jaro, in Iloilo, contained mestizo settlements left behind by an early tide of Chinese migration, since receded. In Molo's population of 16,000 , only 1,000 or so were mestizos, but it was they who controlled trade, and it was they who owned the carriages in Molo. The best description of their activities, and those of the Jaro mestizos, is that given by Nicholas Loney, British viceconsul at Iloilo in 1857. European goods were brought from Manila to the port of Iloilo by mestizo and Chinese traders, and subsequently distributed at Molo, Jaro, and other large towns.

This branch of the trade is as yet principally conducted by the mestizo dealers of Molo and Jaro, who, on completing their purchase of native-made goods for the Manila market, embark with them (in number of from six to ten, fifteen and sometimes twenty) in the coasting vessels leaving for the capital. The returns for these speculations they generally bring back in foreign (principally British) manufactures, purchased at cheap rates from the large Chinese shopkeepers at Manila. The sale of these goods by retail here is still conducted in the rather primitive way of conveying them from place to place on certain fixed days. In this way goods that appear to-day at the weekly fair or market of Jaro, are subsequently offered for sale at Molo, Mandurriao, Oton, or Arevalo. They are carried to and from the different pueblos in cumbrous, solid-wheeled vehicles, drawn by buffaloes and oxen, a mode of conveyance which, during the wet season, is attended with al good deal of delay and risk. ${ }^{71}$

Bowring further points out that mestizos of Molo and Jaro who traded with Manila, in many cases owned their own ships and had much invested in the trade, The items for export to Manila and hence overseas included leaf tobacco, sugar, sapanwood, rice, hemp, hides, horns, sea slugs, mother-of-pearl, and beeswax. Another enterprise in which the Molo-Jaro mestizos were engaged was the manufacture of piña cloth, which was also an export item. Piñamaking was a home industry, and in the house of the mestizos and rich indios there were from six to a dozen looms at work making it.

68. Ibid.x I, p. 311.

69. Manuel Buzeta, O.S.A, and Felipe Bravo, O.S.A., Diccionario geogräfico, estadistico, histórico de las Islas Filipinas (2 vols; Manila 1850), I, pp. 552-53.

70. Jagor, p. 302.

71. Bowring, pp. 114, 359, 377, 400-03. 


\section{THE CHINESE MESTIZO IN PHILIPPINES}

Indeed, according to Loney, piña goods were the most profitable item for sale that the mestizos of Molo-Jaro took to Manila. ${ }^{72}$

Thus, as in landholding, the influence of the mestizo in internal trade was very great. How can we explain the rise of the mestizo to such economic importance from 1750 to 1850? Let us briefly consider the nature of economic opportunities and the kind and amount of economic competition that prevailed in the Philippines during that century.

In an excellent, and as yet unpublished dissertation, Benito Legarda, Jr. has identified the period from about 1820 to about 1870 as one in which the Philippines moved from a subsistence economy to an export crop economy. It was during those fifty years that such Philippine raw products as hemp and sugar began to be exported in quantity and that the products of European factory industry, particularly English textiles, began to find markets in the Philippines. As Legarda points out, a major factory in this economic transition was Western entrepreneurship. North European and North American merchants had access to capital and to markets in the West. Once the Spanish government reversed its longstanding policy and allowed non-Spanish Europeans to reside in the Philippines a necessary precondition for developing an export crop economy had been met. $^{73}$

The expansion of overseas markets for Philippine products in turn stimulated an increase tempo of raw product collection within the archipelago. For those who could do this efficiently there were rapidly expanding opportunities for profit. But the developments of this fifty year period were, in many respects, simply an acceleration of trends that had been in motion in the Philippines since the middle of the eighteenth century. In other words, although the opportunities for middleman wholesalers of raw products and foreign imports expanded rapidly after 1820, such opportunities existed and were slowly growing from the middle of the eighteenth century onward. During the waning years of the Manila Galleon trading system, the galleons, which had once carried primarily Chinese goods and Mexican silver, began to load more diversitied cargo, including increasing amounts of Philippine produce. The Royal Philippine Company, established late in the eighteenth century as a trading device, was also charged with pro-

72. Ibid., pp. 359, 377, 394-97, 400-03.

73. Benito Legarda, Jr., Foreign Trade, Economic Change, and Entrcpreneurship in the Nineteenth-Century Philippines (Harvard University, 1955). See also his "American Entrepreneurs in the 19th-Century Philippines," Explorations in Entrepreneurial History, IX, No. 3 (Feb. 1957). 


\section{THE CHINESE MESTIZOO IN PHILIPPINES}

moting the development of Philippine products and their sale overseas. As Philippine lands began to be used for commercial agriculture, the acquisition of such lands came to be a competitive matter. Opportunities for collectors of Philippine products also began to open up. Who would seize them?

Spaniards and Spanish mestizos were few in number in the Philippines, and, more important, they were usually uninterested in trade, other than speculation in the Manila Galleon. Most indios lacked the capital or experience. ${ }^{74}$ There remained the provincial governors (Spaniards), the Chinese, and the mestizos. The indulto de comercio gave the governors the privilege of trading as a perquisite of office, a special dispensation they enjoyed until $1844 .{ }^{74}$ But although they competed with the mestizos in the collection of Philippine raw products, their method was to acquire raw products as payment in kind of the tribute required of all indios and mestizos, then converting these into cash at a profit to themselves. The mestizos seem to have been more active collectors and transporters of Philippine produce. But except for this difference, which may not be significant, it is not clear why the mestizos should enjoy any advantages over their major competitors, the provincial governors. $^{75}$

Where, for instance, did the Chinese mestizos; get the capital to engage in trading operations and in moneylending? Why did they have such an aptitude for matters of this kind? The simplest answer to both these questions is that both capital and financial aptitude were legacies from their Chinese fathers. Indeed, the commercial skills of the mestizos were said by some observers to have been "inherited" from their Chinese fathers. But because the Chinese father was often absent when the children were growing up, it would seem that in business, as in religion, the mother would have been the teacher. In any event, we have no documented cases to support generalizations about inheritance or family training.

What about the Chinese as competitors of the mestizos? Elsewhere ${ }^{76}$ I have attempted to demonstrate that the mestizo successes of 1750-1850 were accomplished during a slack period of Chinese colonization in the Philippines. This argument, in turn, rests upon demonstration that the oft-repeated Spanish legislation limit-

74. Del Pan, Las Islas Filipinas, p. 243; O. D. Corpuz, The Bureaucracy in the Philippines (Quezon City, 1957), pp. 101-03.

75. On the practices of the governors before 1844 see Legarda, Foreign Trade, pp. 319-21. On mestizo-governor rivalry see Mallat, II, p. 135. See also BR, LI, pp. 234-35, 245-46.

76. Wickberg, The Chinese, Part 1 . 


\section{THE CHINESE MESTIZO IN PHILIPPINES}

ing the size and geographical distribution of the Chinese population, so often evaded in the past, was really enforced during this period. In my view, it was. The defection of so many Chinese - including Catholic Chinese - to the side of the enemy during the English invasion of the Philippines (1762-64) was, I think, a greater shock to the Spaniards than previous Chinese "rebellions" or threats of rebellion had been. For the first time, since the earliest days of the colony, the Philippines had come very near to being lost to Spain - this, with the aid of the Chinese. There was, therefore, good reason to enforce the laws expelling most of the Chinese.

On the other hand, the Chinese had their partisans, and a figure of about 4,000 "necessary" Chinese was cautiously established in 1790. ${ }^{77}$ The actual number residing in the Philippines from the 1780 's to the 1840's exceeded this, and possibly also the figure of 5,000 which appears in official statistics of the period. But it is doubtful that it approached the soaring figures of 20,000 and 30,000 at which it stood in earlier years. Moreover, the Chinese were restricted to Manila and a few provinces immediately adjacent to it. ${ }^{7 s}$ They were in no position to compete with the Visayan mestizos as collectors of Visayan produce.

Therefore, I would argue that the mestizos' economic successes were achieved in large part due to a temporary absence of the Chinese from most of the provincial areas. Had there been no restrictions on Chinese immigration and geographic mobility, the new opportunities that began to appear in the late eighteenth century would, in all probability, have been seized by the Chinese. ${ }^{79}$ Instead, the temporary application of the Spanish laws gave the growing mestizo group its opportunity, with only the provincial governors as its competitor.

The rise of the mestizos to economic importance was paralleled by a rise in social prominence. Indeed, the mestizos' wealth and the way they spent it made them, in a sense, the arbiters of fashion in Manila and in other large settlements. Although they built up their savings, sometimes into real fortunes, ${ }^{80}$ the Chinese mestizos were fond of gambling and ostentation, especially in dress. Besides entertaining friends and others with sumptuous feasts,

77. PNA, Reales órdenes, caja 49, número 96.

78. Berriz, Anuario 1888, I, pp. 576, 594. Discussion in Wickberg, The Chinese. See also Nicholas Loney's comments on the scarcity of Chinese in the provinces as late as the middle of the nineteenth century. Bowring; pp. 400-03.

79. Note Bowring's comparative comments about British Borneo. Bowring, p. $115 n$.

80. Del Pan, Las Islas Filipinas, p. 399. 


\section{THE CHINESE MESTIZO IN PHILIPPINES}

mestizo families often expended great sums of money on feast days. In these things they were a model for the indios, and indio principales who could afford to do so, attempted to live like the mestizos. ${ }^{81}$

There was, in fact, social prestige attached to being considered a Chinese mestizo. Sinibaldo de Mas, writing around 1840, remarks on the rise of wealth, rather than lineage considerations, as the standard of social status. ${ }^{82}$ Although this may be an exaggeration in terms of the archipelago as a whole, for Manila and other urbanized centers it was certainly the case. It was probably true also for those rural areas most affected by the development of an export crop economy. ${ }^{83}$ With the growth of the idea of status by wealth it is not surprising that the Chinese mestizos should become envied models. In the localities where they were numerous, they were often among the wealthiest people, and, what is perhaps more important, they were believed to be, as a class, wealthier than the indios. Hence, great prestige came to be attached to the name "mestizo". Indeed, there were some places in Central Luzon where everyone in the region claimed to be mestizo, even though this meant paying double tax. ${ }^{84}$ The best illustration of this kind of mestizo-craze attitude may be found in the character of Capitan Tiago in Rizal's novels. Capitan Tiago is an excellent example of an indio cacique of means who wished to be regarded as a Chinese mestizo and was able to purchase for himself a place in the wealthy and famous Gremio de Mestizos de Binondo.

Yet the indio attitude toward the mestizo was not one of unmixed admiration. In many areas the mestizo was, after all, the indio's landlord and moneylender, and even if Zúüiga's and Mallats desscriptions of mestizo practices are exaggerated, no doubt there was some basis for hostility in this kind of relationship. ${ }^{85}$ Moreover, in

81. Ibid., pp. 399-400; Mallat, II, pp. 134-35; Buzeta and Bravo, p. 244; Comenge, pp. 214-15; Friedrich Ratzel, Die chinesische auswanderung (Breslau, 1876), p. 135.

82. BR, L.II, pp. 61-62.

83. Del Pan believed that by the 1870 's it was true for all provinces. Las Islas Filipinas, p. 348. Pardo de Tavera's observations are also worth quoting here: "In the same manner as, by the arrival of the Spaniards, the old Filipino caciques were subjected to the Spanish officials, now the caciques, who dominated during the period of tutelary sequestration, found themselves immediately supplanted and converted into something lower than the new caciques of the economic order." Quoted in Conrado Benitez, History, of the Philippines (Rev. ed; Manila, New York, 1954), p. 323.

84. Mallat, II, p. 135 .

85. Comments on mestizo-indio animosity are found in BR, LII, p. 64; Jagor, p. 33; and (for later in the nineteenth century), Edmond Plauchut, "L'Archipel des Philippines," Revue des deux mondes, XX (1877), p. 904; José Montero y Vidal, El Archipićlago Filipino y las Islas Marianas y Palaos, (Madrid, 1886), p. 151; and :Eduardo Navarro Ordóñez, O.S.A., Filipinas, Estudios de algunos asuntos de actualidad (Madrid, 1897), p. 105. 


\section{THE CHINESE MESTIZO IN PHILIPPINES}

towns where there were enough mestizos to form a Gremio de Mestizos, that body and the Gremio de Indios of the town were natural competitors for prestige and local power. There were, in fact, many petty disputes between mestizo and indio gremios and their litigation dragged out over the decades. ${ }^{86}$ Finally, in 1840 , the Spanish government ruled that in towns where there were two gremios the head of the indio gremio was superior to the mestizo head, and that, in case of the death or absence of the local Spanish official, the indio official should take charge. ${ }^{87}$ This ruling did not, however, terminate the disputes. In particular, an ancient contest between the mestizos and indios of Binondo continued on to the end of the Spanish period. More will be said about this below.

With the rise of the mestizos to a position of affluence and prestige, their relations with the indios became a matter of increasing concern to the Spanish. This was especially the case once the Spaniards began to fear the possibility of revolution in their Philippine colony. With the loss of the Latin American colonies, the Spanish began to worry about the eventual defection of the Philippines and to consider what measures ought to be instituted to prevent it. It is from this time - the middle of the nineteenth century - that we begin to find the "divide and rule" theme in Spanish writings. Sinibaldo de Mas, in a secret report of 1842, keynoted subsequent Spanish discussions of the Chinese mestizo in the Philippines. If eventual independence of the Philippines from Spain was desired, he argued, then intermarriage, and the enlargement of the mestizo population ought to be encouraged by every means. But if Spain wished to retain the Philippines, then only a strict policy of divide and rule could be effective. In particular, the indios and mestizos must be kept separated. Or, as he put it, the brains and money of the mestizos must not be allowed to become allied to the numerical strength of the indios. The separate gremios should be maintained and their rivalries encouraged wherever possible. ${ }^{88}$ From this time onward, Spanish conservatives were haunted by fears of an indio revolution led by mestizos.

86. BR, LII, p. 64; PNA, Gremios, 16-5-5; PNA, Provincial Documents, legajo 117, número 70; legajo 56, número 11.

87. BR, LII, p. 64; $\mathrm{PNA}_{4}$ Gremios, 16-5-5.

88. BR, LII, pp. 44-65, 85-87. See also Mallat, II, p. 289 and Buzeta and Bravo, I, p. 214. Although Spanish conservatives favored a "divide and rule" policy, some Spanish liberals advocated the encouragement of intermarriage, on the assumption this would produce a "superior" mestizo society. For an extreme statement of this viewpoint see Raimundo Geler, Islas Filipinas (Madrid, 1869), summarized in W. E. Retana, Aparato bibliográfico de la historia general de Filipinas (3 vols; Madrid, 1906), II, p. 752. 


\section{THE CHINESE MESTIZO IN PHILIPPINES}

Were there grounds for such fears? In terms of mestizo motives, the answer is not easy to find. Historically, the mestizos had supported Spanish rule on more than one occasion. During the various Chinese revolts of former centuries the mestizos had either sided with the Spanish or else taken no part. The mestizos of Binondo were especially proud of their record in this respect, and repeatedly called attention to it, styling themselves "true sons of Spain." ${ }^{9}$ There was even, for a time, a special mestizo militia unit, the Regiment of the Prince Royal, although this body, like so many mestizo institutions, may have existed more for prestige than for practical purposes.90 In any event, the mestizos did not side with the Chinese against Spanish rule. Nor do we find, when we examine indio revolts against Spanish rule, any pattern of mestizo participation.

If the mestizos' political record was apparently pro-Spanish, their cultural record was certainly so. There seemed to be no attachment to Chinese culture, and, instead, a very strong affinity for a Philippine version of Hispanic culture. Their interest in Catholicism was particularly strong. Individually and corporately they generously endowed local Catholic churches, the centers of local Spanish cultural influence. Their contests with the indio gremios were very often over matters of precedence in religious festivals, seating in the churches, and the like.91 Even the mestizo way of dress, so far from showing any Chinese influence, was a semi-European, semi-indio style - a style also affected by the Spanish mestizo in the Philippines. The illustrations of mestizo dress one finds in Mallat - in particular the man's dress, with high silk hat and knee-length shirt - were models of what the urbanized hispanized Filipino of the late nineteenth century would wear. The Chinese mestizo, celarly, was as hispanized - if not more so - as was the urbanized indio.

Why was this so? Perhaps it was a matter of urban influence; most mestizos, by preference, and by family origin, lived in towns - many in the city of Manila. Family fragmentation may have also been a factor; the usual absence of the Chinese father resulting in the rearing of the child by his hispanized, Catholicized mother. Whatever the case, the Spanish Philippine influence was clearly present, centering upon a devotion to Catholicism.

89. PNA, Gremios, 16-5-5.

90. Jean Francois de Galaup de la Perouse, A Voyage Around the World in the Years 1785, 1786, 1787 and 1798 (3rd ed; 3 vols; London, 1807), I, p. 521; Comyn, p. 203.

91. PNA, Gremios, 16-5-5; PNA, Provincial Documents, legajo 117, número 70; legajo 56, número 11. "They are all Catholics." Mallat II, p. 135. 


\section{THE CHINESE MESTIZO IN PHILIPPINES}

It was precisely this quality of hispanization that made the mestizo seem dangerous to the Spanish. A Chinese mestizo of Chinese cultural outlook could not persuade the hispanized, proCatholic indio to join him in revolt. A pro-Catholic, hispanized mestizo, living close to the indio, could.

But why would a mestizo want to revolt against Spanish rule? Under it he had enjoyed prosperity and a certain prestige. But that very prosperity and prestige might serve to whet appetites for still richer prizes - ones that exceeded the opportunities allowed by Spanish policy. In that case, the mestizo was as likely as the indio to revolt.

\section{III. $1850-1898$}

For the mestizo the last half of the nineteenth century was a period of occupational rearrangement and social Filipinization. To a large extent, these two phenomena were results of changes in Spanish policy in the middle and late nineteenth century. By mid-century the transition to an export crop economy was well under way. The Spanish government had decided upon a policy of promoting the economic development of the archipelago along this particular line. Free enterprise was to be given an opportunity to make the Philippines a profitable colony for Spain. As part of this general policy, in 1844, the Spanish government revoked the indulto de comercio and henceforth forbade Spanish officials to involve themselves in trading. This measure, retiring their major competitor from the field, would seem to have removed the last obstacle to mestizo dominance in internal trade, at a time when such trade was rapidly expanding. Yet it was not the mestizos that reaped the benefits; it was the Chinese. At the same time the provincial governors were removed from the field, Spanish policy also pushed aside the barriers to Chinese immigration and residence. Now, for the first time, Chinese could come to the Philippines without restriction as to number and with little if any restriction as to where in the archipelago they might reside. By the 1880 's the Chinese population had soared to almost 100,000 - a figure several times that of any previous high - and Chinese were found in every corner of the Philippines. ${ }^{92}$

This new influx of Chinese had a profound effect upon the mestizos. Although the nature and extent of that effect are not fully clear as yet, there are certain strong indications. Occupationally, the result was a partial abandonment of commerce and a

92. Wickberg, The Chinese, esp. Part II. 


\section{THE CHINESE MESTIZO IN PHILIPPINES}

transition to other occupations. In some areas - notably Central Luzon, this meant an increased concentration in agriculture; elsewhere it resulted in occupational diversification. In Central Luzon, the fate of the "mestizo towns" is not entirely clear. Tambobong (Malabon) held on to its position as provisioner of Manila. ${ }^{93}$ Otherwise, some of the towns seem to have declined. Del Pan makes a sweeping statement to the effect that the decline of the rich gremios de mestizos in several Luzon towns was the result of Chinese commercial competition. Although Chinese competition was surely a factor of importance, it must be remembered that Del Pan's argument is part of an anti-Chinese diatribe in which most of the ills of the Philippines are blamed upon the Chinese immigrant. ${ }^{94}$ The fate of the mestizo wholesalers in Central Luzon is not clear, but it is apparent that mestizo retailers in this area were widely forced out of business by Chinese competition and shifted their attention to agriculture. ${ }^{95}$ In the city of Manila, mestizo merchants in Barrio Santa Cruz were overwhelmed by the Chinese. Some of them turned to speculation in government supply contracts; others became skilled craftsmen. ${ }^{96}$

In the Visayas, mestizo enterprise in Cebu and Molo-Jaro was seriously affected by the intrusion of both the Chinese and the North European and North American merchant entrepreneurs. The prosperity of the mestizos in these two regions had been built in large part upon their ability to bring Visayan produce to Manila for export, taking back foreign manufactures for sale in the Visayas. But once the ports of Cebu and Iloilo were opened to international trade in the 1850's, and once the Chinese and the foreign merchant-entrepreneurs were allowed to reside at those ports, it became possible for international traders to do business directly in the Visayas instead of waiting for the mestizo to come to Manila. Direct international trading in Cebu and Iloilo was much cheaper because it eliminated the mestizo middle-man interisland trader. ${ }^{97}$ The mestizos of Molo and Jaro, therefore, cut back their trading interests in the face of more efficient foreign com-

93. Del Pan, Las Islas Filipinas, p. 362.

94. Los Chinos en Filipinas, ed J. F. del Pan (Manila, 1886), pp. 110, 18-19.

95. Ibid., pp. 27-28, 64-65. However, it is evident that some mestizos remained in commerce, as, for instance, those of Dagupan and Calasiao in Pangasinar, who were still the precminent traders of their region in 1901. Gregorio Flormata, Memoria sobre la Provincia de Pangasinan (Manila, 1901), p. 20

96. Del Pan, Las: Islas Filipinas, pp. 69, 358.

97. Jagor, pp. 303-05, 347; Benitez, pp. 238-39; Robustiano Echáuz, Apuntes de la Isla de Negros (Manila, 1894), p. 24. Although, according to Del Pan, Chinese competition caused the decline of the Cebu gremio de mestizos, there was still a separate census entry for the barrio of the Parian as late as 1903. Census of the Philippine Islands Taken Under the Direction of the Philippine Commission in the Year 1903 (4 vols; Washington, 1905), II, p. 156. 


\section{THE CHINESE MESTIZO IN PHILIPPINES}

petition by the Chinese and the Westerners, and concentrated on their cloth-weaving industry and the development of sugar production on adjacent Negros.98 How they acquired the use or ownership of sugar lands in Negros is not known. We have only a quotation from Jagor:

the result has been that, as much to their own profit as to that of the country, they have betaken themselves to the cultivation of sugar. In this manner important plantations have been established in Negros, which are managed by natives of Yloilo . . . 99

The reaction of the Cebuan mestizos to the loss of their interisland trading monopoly is not known. Jagor reported that in the 1860 's most of the land on the island of Cebu belonged to the mestizos of Cebu City. It is not clear whether this condition was related to Chinese commercial competition. ${ }^{100}$

The importance of Chinese and other competition in producing a mestizo shift to agriculture in Central Luzon and the Iloilo-Negros region should not be exaggerated. Since the late eighteenth century there had been mestizo landholders in Central Luzon. This may have been the case in the Iloilo area as well. If the number of mestizo landholders and commercial agriculturalists increased during the late nineteenth century it was not alone due to the effects of foreign competition. The new export crop economy-. and also, be it noted, an increase in population-raised the value of land and made landowning and export crop productionanywhere in the Philippines - an attractive means of livelihood. Government legislation, easing the acquisition of good titles, encouraged a trend toward land grabbing in the 1880's. ${ }^{101}$ The mestizos were surely among the "grabbers". By the end of the Spanish period, Retana (no doubt with exaggeration) was writing that the dire prophecies of Zúñiga's day had been realized: the Chinese mestizos had taken over half the lands of the country. ${ }^{102}$

Thus it would appear that by the end of the Spanish period the

98. Jajor, p. 304.

99. Ibid., pp. 304-05.

100. "The owners of the soil know how to keep the peasants in a state of dependence by usurious loans; and one of the results of this abuse is that agriculture in this island stands lower than in almost any other part of the archi. pelago." ibid., p. 302.

101. Del Pan, Las Islas Filipinas, pp. 338-39.

102. "The future is theirs; even in politics." Notes to Zúniga, II, p. 526. Palgrave spoke of the Chinese mestizos as the "most bulky estate-owners". W. G. Palgrave. "The Far-off Eden Isles:" Country Life in the Philippines Fifty Years Ago by a British Consul Manila, 1929), p. 59. Frederic Sawyer, however said the Chinese mestizos owned less land than the Spanish mestizos. The Inhabitants of the Philippines (London, 1900), p. 293. 


\section{THE CHINESE MESTIZO IN PHILIPPINES}

mestizos were, as they had been around 1800 , very much involved in landholding, especially in certain parts of the Philippines, and had added to this an increasing concern with commercial agri culture. But in their other major specialty - commerce - they had failed in the face of renewed Chinese competition. They had thus forfeited their chance to become a native Philippine middle class, a fate that had been predicted for them at mid-century. ${ }^{103}$ Why, despite their known aptitude for commerce, had this happened? The reasons are not easy to find. Perhaps it was the excessively speculative nature of mestizo trading, as contrasted with more conservative Chinese practices. Or perhaps the mestizo penchant for display and ostentatious living was a factor. Finally, and probably of most importance, the Chinese methods of buying raw materials and distributing imports were superior to methods used by the mestizos. Or, to put it in a few words, the periodic market system of distribution and purchase was no match for the Chinese sari-sari store. ${ }^{104}$

Turning from economic to social matters, it is possible to characterize the condition of the mestizo in the late nineteenth century as one of "social Filipinization". The concept of "Filipinization", in turn, rests upon my belief that in the late nineteenth century, with the decline of the separate, ethnically-determined gremios, the growth of status by wealth and occupation, rather than by custom or ethnic considerations, and the development of Filipino nationalism, a concept of something "Filipino" came into being in the Philippines. That is to say, traditionally, the term "Filipino" was one used by Spaniards to refer to a Spaniard born in the Philippines. It did not refer to any group of people or to any cultural or political entity that had unique characteristics associated only with the Philippines. I am arguing here that in the late nineteenth century there was in process of creation a specifically Philippine society, centering on Manila and its adjacent regions, in which there was a kind of general cultural consensus. That consensus was a blend of Spanish and indio culture that had, been developed and matured over three centuries of Spanish presence

103. Victor Clark's survey of Philippine labor conditions at the beginning of the American period generalizes: "As an agricultural landlord the mestizo is more prominent than the pure Mongolian, but he does not affiliate with the latter and more usually holds aloof from commercial pursuits." Labor Conditions in the Philippines, U.S. Bureau of Labor Bulletin, $\mathrm{X}$ (Washington, 1905), p. 836. On the other hand, the 1903 census indicated that some eighteen percent of the mestizos were in agricultural work and some twenty-one percent in commerce. The problem here is that the 1903 census simply put all half-castes into a "mixed" category. It is therefore impossible; to separate the Chinese mestizos.

104. Wickberg, The Chinese, Part II. 


\section{THE CHINESE MESTIZO IN PHILIPPINES}

in the archipelago. In the creation and promotion of this cultural consensus, the mestizos, as a culturally marginal element, were probably of great importance.

Both Spanish and mestizo observers of the Philippine social scene in the late nineteenth century pointed out the decline of the gremios as functioning political bodies and argued that they should be abolished. ${ }^{105}$ Likewise, they claimed, the tribute should be replaced by some other form of taxation. The tribute dated from a time when it could be assumed that all those who paid it were villagers who possessed little private property. Now Manila had become cosmopolitan, other towns had become urbanized as well, all of them full of mestizos and indios whose status was based upon wealth and occupation, not upon traditional considerations. ${ }^{106}$ In the face of these arguments, the Spanish government abolished the tribute in the 1880 's, replacing it with a general property tax which fell equally upon all classes.

The gremios, however, were not formally dissolved. And the ancient feud in Binondo between the indio and mestizo gremios of that town flared up to new heights during the 1880's. Despite the 1840 ruling that in claims of precedence indio gremio heads were to take precedence over mestizo gremio heads, the situation in Binondo had not conformed to the general rule. It will be recalled that Binondo had been founded as a Chinese town in the late sixteenth century, and that by the middle of the following century it was a Chinese-mestizo community composed entirely of Catholics. As indios had begun to settle within its confines, the Chinese and mestizos reiterated their claims to their ancient privileges. Repeatedly, these claims were confirmed by the government. Even after 1840, when the indio gremios were elsewhere triumphant, in Binondo, the mestizo gremio maintained its position. During the 1880's mestizo-indio rivalry in Binondo flared up once again. The occasion was the celebration of the religious festival of La Naval. The mestizos had always defrayed the expenses of this festival in Binondo and had always enjoyed a preferred status in its ceremonies. But in 1887 the Spanish governor inexplicably reversed the order, giving precedence to the indio gremio. For several days Binondo, the commercial center of Manila, was tense.

105. Del Pan, Las Islas Filipinas, pp. 356, 358; Grcgoria Sancianco y Goson, Fil progreso de Filipinas. Estudios económicos, administrativos y politicos. Parte económica (Madrid, 1881), pp. 104-18.

106. Del Pan, Las Islas Filipinas, pp. 347-48. One abortive Spanish attempt to adjust to the new situation without changing the old tax system may be scen in an attempt of 1851 to force mestizos who lived in masonry houses to pay double the ordinary mestizo tribute. San Pedro, VIII, pp. 408, 410-11. 


\section{THE CHINESE MESTIZO IN PHILIPPINES}

Eventually, the decision was reversed, amid a torrent of mestizo and indio assertions of eternal loyalty to Spain. ${ }^{107}$

Was there any significance to this incident? At the same time it occurred a group of indios and mestizos was daringly presenting to the government a petition to expel the Spanish regular clergy from the islands. Radical sentiment was building up. The government's decision to restore the mestizos to their privileges was probably not a matter of seeking to maintain mestizo support, but rather a conservative feeling that in the face of growing radicalism the best policy was to avoid disturbing the status quo.

What did the mestizos and indios want? Simply, precedence in ceremonial affairs. In the seventeenth and eighteenth centuries and even in the early nineteenth century - when the issue of precedence had been raised, there was more at stake than ceremonial. The right to take charge of police and other functions of the town - and, ultimately, in the eyes of the mestizos, at least the question of who owned the land on which Binondo had been built -- all these things were at issue. But in the late nineteenth century Binondo was no longer a separate town. The city of Manila had expanded to incorporate it, and municipal government had replaced gremio government. Binondo was now the cosmopolitan commercial center of a cosmopolitan city. The gremios, in practical terms, were unimportant. They remained only as status groups. Seen in this light, the significance of the $1887 \mathrm{La}$ Naval incident is that it demonstrates the changed historical context in which the ancient mestizo-indio dispute survived. All that was at stake now was social prestige.

But if gremio rivalries might persist, individual relationships were less and less bound by such matters. And with the abolition of the tribute in the 1880's there were simultaneously abolished the legal distinctions of "indio" and "mestizo". Henceforth, each individual was identified as society might wish or as he himself might choose. It was no longer a legal matter. Increasingly, definitions were simplified and nationalized: one was either a Spaniard, a Filipino, or a Chinese. ${ }^{108}$ Faced with a choice, few mestizos chose to be considered Chinese ${ }^{109}$ : they could not choose to be con-

107. PNA, Gremios, 16-5-5.

108. Wickberg, The Chinese, Part III.

109. The Chinese community of later years honored the momory of Ildefonso Tambunting, as one of a very few prominent mestizos who openly indentified themselves as Chinesc and followed Chincsc customs. Fei-lú-p'in Min-li-la Chunghua Shang-hui san-shih chou-nien chi-nien k'an (Thirtieth Anniversary Commemorative Publication, Manila Chinese Chamber of Commerce), ed. Huang Hsiao-ts'ang (Manila, 1936), p، 198. 


\section{THE CHINESE MESTIZO IN PHILIPPINES}

sidered Spaniards. By the late nineteenth century, the culture that they espoused and represented had become "Filipino" culture. It is not surprising that the mestizos chose to be regarded as "Filipino". But this choice ensured that any separate status as "mestizo" would have difficulty enduring, if, indeed, they wished it to do so. There was by now no separate mestizo sub-culture; there was now no separate legal classification; the gremios were dying. The age of the mestizos as a separate group was passing.

When the Philippine Revolution broke out mestizos were involved - but not necessarily as mestizos. As pointed out above, many Spaniards had long feared an indio revolution led by mestizos. And there were Spaniards who so interpreted the Revolution when it finally came. Unquestionably, many mestizos participated prominently in the Revolution in several ways. The financial contributions of some are quite well known. Many others were partisans of the movement that favored reform over revolution. Still other mestizos were imprisoned, on suspicion of complicity and released by the Spaniards only after paying huge ransoms. Their imprisonment was more a matter of extortion than anything else. ${ }^{110}$

But there were Spaniards who simply blamed the Revolution on the mestizos. One Spanish writer said that unlike the indios and Spanish mestizos, who were loyal to Spain, the Chinese mestizos were insincere and seditious, just as their Chinese forefathers had been in the earlier centuries of the colony. The mestizos, this writer claimed, had joined themselves "ardently" to the insurrection, "with their influence, their persons, and their funds." 111 Another Spaniard wrote: "The mestizo race is the major enemy of Spain, as contrasted with the indios, who are most loyal and grateful to the mother country." 112 Even non-Spanish foreigners who resided in Manila had acquired an unfavorable view of the mestizos, who were regarded as conceited, petty, crafty, and, as citizens, "discontented."113

Were the mestizos "discontented"? We have suggested above

110. LeRoy, Americans, I, p. 279. See biographies of Telesforo Chuidian, Mariano Limjap, Roman Ongpin, and Francisco Osorio in E. Arsenio Manuel, Dic. tionary of Philippine Biography. Volume One (Quezon/ City, 1955), pp. 13133, 248-50, 295-97. Sce also Foreman, p. 523; T.H. Pardo de Tavera, Biblioteca Filipina (Washington, 1903), p. 129; Sawyer, p. 81; and biographical sketch of Luis R. Yangco in Samuel W. Stagg, Teodoro Yangcos Leading Filipino Philanthropist and Grand Old Man of Commerce (Manila, 1934), p. 28.

111. Navarro Ordóñez, pp. 105-06.

112. Montero, p. 151.

113. See testimonies in Report of the Philippine Commission, II, pp. 17-19, 167, 187-90, 198-201, 204-06, 216, 229. Other Spanish comments are found in Commenge, pp. 213-14 and in the newspaper La Politica de Españe en Filipina June 23, 1891, p. 117 and September 13, 1892, p. 241. 


\section{THE CHINESE MESTIZO IN PHILIPPINES}

that they might become so if their ambitions, whetted by achievement of some prosperity and prestige, should then be thwarted. It is not clear whether this happened. But it is of significance to quote here the well-known observation of Pardo de Tavera regarding the social and political impact of economic change in the nineteenth century Philippines.

Bigan, Taal, Balayan, Batangas, Albay, Nueva Caceres, Cebu, Molo, Jaro, Iloilo, began to be covered with solidly constructed buildings; their wealthy citizens would come to Manila, make purchases, become acquainted with the great merchants, who entertained them as customers whose trade they needed; they visited the Governor-general, who would receive them according to the position that their money gave them; they came to know the justices of the Supreme Court, the provincials of the religious orders ... and, on returning to their pueblo, they took in their hearts and minds the germ of what was subsequently called subversive ideas and later still 'filibusterismo' . . . Already the 'brutes loaded with gold' dared to discuss with their curate, complain against the alcalde, defend their homes against the misconduct of the lieutenant or sergeant of the police force ... Their money permitted them to effectively defend questions involving money first, then, those of a moral character. ${ }^{114}$

If what I have said about the mestizo role in the Philippine economy is true, some of these "brutes loaded with gold" were surely mestizos.

Yet we need not believe that all the "brutes loaded with gold" who challenged the order of things were mestizos. Nor should we attribute the Revolution to mestizo discontent or a mestizo plot. That Spanish conservatives did so may be partly explained by their scorn of the indio. Their practice was to assign credit or blame for any act that took some initiative to mestizos, in order to underline the assumed incapacity of the indio for anything but animal's work. This disparagement of the indio as a brute is one form of Spanish reaction to the pretensions of Filipino nationalism in the late nineteenth century. ${ }^{115}$

It is more likely that mestizo participation was part of an increasing trend toward identification in interests of indio and mestizo. Sancianco, a Spanish-trained mestizo lawyer, pointed out in the 1870's that recent revolts had had this character, and that

114. Quoted in Benitez, p. 335.

115. Sancianco, pp. 223-237; Census, I, p. 380. See also Jesus Z. Valenzuela. A History of Journalism in the Philippine Islands (Manila, 1933), pp. 43-44, 90-92. 


\section{THE CHINESE MESTIZO IN PHILIPPINES}

it was futile for Spain to try to emphasize differences when those differences were being blurred in common action. ${ }^{116}$ Thus, the mestizo was undergoing a process of "political Filipinization" as well as "social Filipinization."

\section{Summary}

Our knowledge is still insufficient to allow us to assess the overall significance of the mestizo in Philippine history. But on the basis of what we now know we can make some generalizations and some hypotheses for future study. It is clear, in the first place, that the activities I have described are those of Chinese mestizos - not Spanish mestizos. While the Chinese mestizo population in the Philippines exceeded 200,000 by the late nineteenth century, ${ }^{117}$ the Spanish mestizo population was probably never more than $35,000 .{ }^{118}$ Furthermore, those who commented at all on the Spanish mestizo noted that he was interested in military matters or the "practical arts" - never in commerce. The aptitudes and attitudes of the Chinese mestizo were in sharp contrast to this. ${ }^{119}$

Secondly, the Chinese mestizo rose to prominence between $174 \mathrm{I}$ and 1898, primarily as a landholder and a middleman wholesaler of local produce and foreign imports, although there were also mestizos in the professions. The rise of the mestizos. implies the existence of social change during the Spanish period, a condition that has been ignored or implicitly denied by many who have written about the Philippines. ${ }^{120}$ It needs to be emphasized that the mestizo impact was greatest in Central Luzon, Cebu, and Iloilo. We cannot as yet generalize about other areas.

116. Sancianco, pp. 104-18.

117. Ferdinand Blumentritt, "Die mestizen der Philippinen-Inseln," Revue coloniale internationale, 1, No. 4 (Oct. 1885), pp. 253, 257; Foreman, p. 410; Francisco Ahuja, Reseña acerca del estado social y económico de las colonias de España en Asia (3 vols; Madrid, 1874-75), III, pp. 20-21; Ramón González Fcrnández and Federico Moreno Jérez, Manual del viajero en Filipinas (Manila, 1875), pp. 51, 93.

118. Eestimates of the number of Spanish mestizos vary widely. Mallat (I, p. 97) estimated 20,000; Díaz Arenas cauderno 5) counted 7,515, excluding those in the Marianas; Zamora (VI, p. 104) presents a figure of 11,254. All of these are mid-nineteenth century estimates, made at a time when the total Philippine population was 4,000,000 to 5,000,000 and the Chinese mestizos numbered about 200,000 . The only late nineteenth century estimate I have is one of 1891 (given ir Sawyer, p. 292) which gives the number of Spanish mestizos as 75,000 , and the number of Chinese mestizos as 500,000 . The latter estimate is about twice the actual amount. I suspect the former is equally in error. The Spanish population, at its highest point, was about 34,000 . BR, I.II, pp. $115 \cdot 116$ n.

119. Lannoy, p. 113; Mallat, II, p. 134; Buzeta and Bravo, II, p. 2441 Plauchut, p. 904 .

120. For example, E. H. Jacoby, Agrarian Linrest in Southeast Asia (Chapel Hill, 1950), pp. 85-90; Alvin Scaff, The Philippine Answer to Communism (Stanford, 1955), pp. 86-87. 


\section{THE CHINESE MESTIZO IN PHILIPPINES}

Third, the renewal of Chinese immigration to the Philippines resulted in diversion of mestizo energies away from commerce, so that the mestizos lost their change to become a native middle class, a position then taken over by the Chinese.

Fourth, the Chinese mestizos in the Philippines possessed a unique combination of cultural characteristics. Lovers of ostentation, ardent devotees of Spanish Catholicism - they seemed almost more Spanish than the Spanish, more Catholic than the Catholics. Yet with those characteristics they combined a financial acumen that seemed out of place. Rejecters of their Chinese heritage, they were not completely at home with their indio heritage. The nearest approximation to them was the urbanized, heavily-hispanized indio. Only when hispanization had reached a high level in the nineteenth century urban areas could the mestizo find a basis of rapport with the indio. Thus, during the late nineteenth century, because of cultural, economic, and social changes, the mestizos increasingly identified themselves with the indios in a new kind of "Filipino" cultural and national consensus.

Those are my conclusions. Here are some hypotheses, which I hope will stimulate further study:

1. That today's Filipino elite is made up mostly of the descendants of indios and mestizos who rose to prominence on the basis of commercial agriculture in the latter part of the Spanish period. That in some respects the latter part of the Spanish period was a time of greater social change, in terms of the formation of contemporary Philippine society, than the period since 1898 has been.

2. That in the process of social change late in the Spanish period it was the mestizo, as a marginal element, not closely tied to a village or town, who acted as a kind of catalytic agent. In this would be included the penetration of money economy into parts of the Philippines. There were areas where the only persons with money were the provincial governors and the mestizos. ${ }^{121}$

3. That the Chinese mestizo was an active agent of hispanization and the leading force in creating a Filipino culture characteristic now of Manila and the larger towns.

4. That much of the background explanation of the Philippine Revolution may be found by investigating the relationships between landowning religious orders, mestizo inquilinos, and indio kasamahan laborers.

121. BR, LI, pp. 235-39. 


\section{THE CHINESE MESTIZO IN PHILIPPINES}

It is my hope that these hypotheses may stimulate investigation into this important topic which can tell us so much about economic, social, and cultural change during the Spanish period of Philippine history. 